\title{
Analysing the Future of International Criminal Justice in Africa: A Focus on the ICC
}

Emily Wakesho Ngolo*

\begin{abstract}
The International Criminal Court has generally a bad reputation in the African continent as a whole with hostile assertions by the African Union, that the court is nothing but a political tool for the powerful. The Court, plagued with numerous difficulties, has come under pressure to perform, with some doubting its viability. Created by the Rome Statute, and the parties therein governed by general treaty law, enforcement mechanisms of the court have been unsatisfactory at best and this has led to questions being asked as to its survival. There exists a pool of divergent views, in regard to the African Union and the International Criminal Court, in many of the crucial areas of international criminal justice. This paper seeks to find out just how true is the claim that the ICC is 'dead' is, and the implications of this in the future of the continent as regards international criminal justice. How important is it for us to preserve international criminal justice? fust how much of a role do states play in this revered area of law? Is its legal viability coming to an unfortunate premature end? What does this mean, then, for the victims of mass atrocities? This paper seeks to show an interplay of the role of states and politics in international criminal justice, and determine then, whether there exists any bright future for this area of law in Africa.
\end{abstract}

\section{Introduction}

International criminal justice, albeit plagued by numerous pitfalls, is one of the areas of law that should be revered the world over. ${ }^{1}$ Its purpose is to ensure

* The author is a student at the Strathmore University Law School in Nairobi, Kenya.

'Donovan D: “International Criminal Court: Successes and Failures', International Policy Digest, http://www.internationalpolicydigest.org/2012/03/23/international-criminal-court-successes-andfailures-of-the-past-and-goals-for-the-future/ on 25 November 2015. 
that those crimes considered to be of a grave nature against the whole of humanity do not go unpunished. ${ }^{2}$ Indeed, the very first time in history that this area of law was formally recognized was at the World War II trials at Nuremberg. ${ }^{3}$ The basis of the criminalisation and punishment of the Nazi atrocities in the 1930s was that the world could not tolerate their being ignored, because they could not tolerate their being repeated, and this was rightly said by Justice Robert H. Jackson, who was the then chief prosecutor of the United States at the Nuremberg trials. ${ }^{4}$ The importance of international criminal justice cannot, therefore, be trivialized. In order to assess the future of this crucial area of law in our great continent, we need to have a sense of its nature. It is important to note, notwithstanding, the vital nature of this area of law, that international criminal courts and tribunals acquire their power and legal mandate from many divergent sources, and this ultimately has the effect of rendering their efficiency wanting. ${ }^{5}$ A close look at the International Criminal Court (herein after referred to as the ICC), vis-à-vis other types of international criminal tribunals, as we shall see in the subsequent parts of this paper, will demonstrate the exact extent of this.

There are a number of issues that have continued to haunt the international criminal law system, an important one being politics; politics, because of the primacy of states in this branch of law. The two areas have been viewed as separate for a long time but a look at international law happenings in history such as the case against Augusto Pinochet, the NATO intervention in Kosovo, the decision of the Security Council not to intervene in the Rwandese genocide, the reluctance of the Security Council to intervene in Syria, or their standoff as regards the war in Iraq or the war against terrorism as it is now, show close proximity between international law and politics. ${ }^{6}$ In the African context, much has been said about the reluctance of judicial systems that are mostly partisan shielding those who ought to be in trial from the long hand of the law. It has been said that

2 See, Damasaka M, 'What is the Point of International Criminal Justice?' Yale Law School legal scholarship repository (2008).

3 International Military Tribunal at Nuremberg. Also see, The London Declaration of 8 August 1945 on the Agreement for the Prosecution and Punishment of Major War Criminals of the European Axis.

4 See the statement by Justice Jackson in the opening address to the International Military Tribunal at the Nuremberg Trials, November 10, 1945, https://en.wikiquote.org/wiki/Robert_H._Jackson on 28 November 2015.

5 There is no specific basis for the formation of international criminal tribunals. The ICC for example was created by the Rome Statute and is a treaty-based court and the only permanent one. Others such as the ICTY and ICTR were formed on an ad hoc basis by the United Nations which makes aspects such as cooperation easier because they are governed by the Security Council.

6 Reus-Smit C, The Politics of International Law, Cambridge University Press, 2004, 1. 
there are a number of situations where political pressure may be too great even for national independent systems to deal with. ${ }^{7}$

International criminal tribunals have limited power beyond that which states accord them, because of the basic reason that states are at the centre of the formation of such tribunals; this is true more so for the ICC, which is founded by treaty. They are dependent on the will of the states, and therefore, the political realities that plague this area of law cannot be downplayed. Since states are at the apex of this, political considerations and decisions, rather than purely legal and objective ones, regarding some of the major issues in this area of law, are prevalent. This has been said to be the reason why international criminal justice, since the World War II era, has been branded a system that promotes justice for the victors. ${ }^{8}$

As regards Africa, the application of international criminal justice has received blows from the majority of countries for that same reason. The ICC has been said to unfairly target Africans, and this has been the stand formally taken by the African Union (herein after referred to as the AU). ${ }^{9}$ The AU has cited this as one of the reasons why they passed a call to all of their members not to cooperate with the ICC. ${ }^{10}$ This view, that international criminal justice is lopsided, has contributed to its effectiveness owing to lack of goodwill by member states. ${ }^{11}$ This view has, however, not been adequately substantiated in the law, as many of the criticisms tend to ignore the principle of complementarity, and to give it credit. Also not taken into account are the various ways in which situations may be brought before the court under the Rome Statute. It is noteworthy that four cases in the ICC were referred to the court by African states themselves. ${ }^{12}$ While taking adequate consideration of the fact that the views of the whole continent of Africa cannot be based on the views of the AU as a whole since there is

\footnotetext{
7 'Complementarity: A working relationship between African states and the International Criminal Court' Max Du Plesis (2008), 137.

8 'Ottilia Anna Maunganidze: The Conflation of Politics and Law: Africa and International Criminal Justice' International Criminal Justice Today, 8 December 2014 bttp://wnw.international-criminal-justicetoday.org/arguendo/Article/ the-conflation-of-politics-and-law-africa-and-international-criminal-justice/ on $20 \mathrm{Au}$ gust 2015.

9 AU, "Decision on the Progress Report of the Commission on the Implementation of Decision Assembly/AU/Dec. 270 (XIV) on the Second Ministerial Meeting on the Rome Statute of the International Criminal Court (ICC)," 27 July 2010, Assembly/AU/Dec.296 (XV).

10 AU, "Decision on the Progress Report of the Commission on the Implementation of Decision Assembly/AU/ Dec.270 (XIV) on the Second Ministerial Meeting on the Rome Statute of the International Criminal Court (ICC), " 27 July 2010, Assembly/AU/Dec.296 (XV), para. 5, 8 and 9.

11 Donovan D, 'International Criminal Court: Successes and Failures.'

12 Jacinto L, 'From Lubanga to Kony: Is the ICC only for Africans?' (2012), 24.
} 
evidence that some African countries in the union do not agree with the union's stance, the effect of this is that it has created a loophole for some to explore the uneven terrain and undermine the international criminal justice system. ${ }^{13}$

What, then, does this mean for the future of the international criminal justice system in Africa? This paper sets out to break down the international criminal justice system in order to determine where Africa lies in the quest for justice for victims of major atrocities committed on African soil vis-à-vis the need to uphold sovereignty as a principle of international law. With particular regard to the ICC, an attempt will be made to study the key areas of contention that continue to exist in the relationship it has with African countries.

Part I of this paper therefore focuses on the reasons why states are crucial players on the international criminal law scene and what certain principles such as sovereignty mean in relation to this. Part II will discuss the duties and obligations, in particular, cooperation, that states have towards the ICC as a treatybased court, and will contrast these with the duties and obligations that would arise from a state, if the court had been of the ad hoc or hybrid nature, such as those that get their powers from the United Nations. Part III of the paper sets out an analysis of the issue of cooperation, in particular the discussion on immunities and arrest warrants, in relation to the continent and the ICC. Part IV sets out to break down and understand the nature of the conflict of interest as regards the states in Africa that are both party to the Rome Statute, and the AU and the solution to this. Part V gives the conclusion.

\section{States as the Primary Actors in International Criminal Justice}

\section{i International Legal Personality}

International legal personality denotes rights, duties and obligations under international law. States remain by far the most important of these in international criminal justice. ${ }^{14}$ States are said to have original personality in international law, and even though with time there has been an increase in the entities that

13 Reuters, Malone B, African nations divided over Bashir genocide charge, 25 July 2010. See http:// uk.reuters.com/Article/idUKTRE66O1NR20100725 on 12 August 2015. See also, as an example of one of the African Countries that did not agree with African Union; Botswana Press Agency, Botswana stands by the International Criminal Court, 2010. http://www.gov.bw/en/News/Botswanastands-by-the-International-Criminal-Court-/on 12 August 2015.

14 Shaw M, International Law, Cambridge University Press, New York, 2008, 195. 
have international legal personality under the law, states maintain the original legal personality while other entities have derivative legal personality. Although international criminal justice connotes individual responsibility, the main legal persons in this area of law are states especially in regard to the practical functionality of courts. ${ }^{15}$

Derivative legal personality under international law means that the states are the ones who give the meaning of personality to other entities such as international organizations as well as individuals. Other entities are limited in their rights and duties; that is, they do not enjoy absolute legal personality and are limited only to the extent of the powers and functions that their constitutive documents, which the states formulate, give them. This was stated in the Reparations Case. ${ }^{16}$

\section{ii Principles of Sovereignty and Complementarity}

As set out in the Montevideo Convention, sovereignty is one of the most important characteristics of statehood. ${ }^{17}$ The International Law Commission defined sovereignty as the ability of a state to provide for its own well-being independent of the dominion of other states. ${ }^{18}$ Sovereignty is the principle that a state has independence and autonomy in its functions, and that no other state can dictate the actions of the state. Respect for state sovereignty is enshrined under the Rome Statute's preamble in paragraph 10 which states that the court shall be complementary to national jurisdictions, and in Article 17 which provides that the court shall render a case inadmissible in the event of it being investigated or prosecuted by a state which has the jurisdiction to do so. ${ }^{19}$ This complementarity role means that a state bears the primary responsibility for investigating and prosecuting a case. It is only when the court has determined that a state is unable or unwilling to institute proceedings that it may interfere..$^{20}$

15 Shaw, International Law, 197.

16 Reparation of Injuries Suffered in service in the United Nations Case, Advisory Opinion, ICJ reports 1949.

17 Article 1, Montevideo Convention on the Rights and Duties of states, 26 December 1933.

18 See, the duties of states prepared in 1949, by the International Law Commission in the Yearbook of the ILC, 1949, 286. See also, Judge Huber's dicta in the Island of Palmas case where he deals with the issue of territorial sovereignty, and talks of the right to the exclusion of all others in the exercise of the functions of a particular state.

19 Article 17, Rome Statute of the International Criminal Court, 17 July1998, 2187 UNTS 3.

20 International Justice Project, Cuzzolino A, 'Cooperating on Non-Cooperation: a brief legal history and analysis of Sudan's non-compliance with the ICC — and the role of the Security Council', 26 June 2015. http:// www.internationaljusticeproject.com/cooperating-on-non-cooperation-a-brief-legal-history-andanalysis-of-sudans-non-compliance-with-the-icc-and-the-role-of-the-security-council on 20 August 2015. 


\section{States as the enforcement mechanisms of the International Criminal Court}

The constitutive document of the ICC is the Rome Statute. It is a treatybased court, the first permanent criminal court in the world, formed by the assembly of the state parties, for the purpose of ending impunity with regard to international crimes. ${ }^{21}$ The court, however, does not have its own enforcement mechanism and therefore depends heavily on the will of states. It does this through cooperation requests, since under the Rome Statute, the state parties have a general obligation to cooperate with the court under Article 86, and the court may request cooperation of state parties under Article 87.22 States have the obligation to cooperate with the court in the exercise of its functions, in many areas such as the execution of arrest warrants and enforcement of prison sentences. A problematic situation is noted here, owing to the fact that the court cannot properly exercise its functions except as dependent on the will of states. The ICC depends on state parties to cooperate, in order for it to exercise its powers. As we shall see (in the subsequent parts of this paper), in the event of non-cooperation, there is only so much that the court can do although, to date, there have been no real punitive actions taken against any state for the refusal to fulfil obligations under the Rome Statute.

We shall see, in the subsequent chapters, examples of how the ICC is actually dependent on the goodwill of states, and is essentially almost powerless without states. In Africa, for example, the court has struggled owing to noncooperation of member states as seen in the situation regarding the execution of the arrest warrant of Omar Al Bashir. There is clearly only so much that the court can do, but ultimately the cooperation of states is the only factor that holds the court together, lest it collapses. ${ }^{23}$ The court, as seen in many instances in the Bashir case, has tried to effectuate its powers by basing arguments in customary law and in the UN charter. ${ }^{24}$ However, it derives its powers from the Rome stat-

21 http://www.icc-cpi.int/en_menus/icc/about $\% 20$ the $\% 20$ court/Pages/about $\% 20$ the $\% 20$ court. aspx on 16 August 2015.

22 Article 86, 87 Rome Statute of the International Criminal Court.

23. AU has told its members not to cooperate with the court. Also, see all the countries that have failed to honour their obligations under the Rome Statute, such as Malawi, Chad and the Democratic Republic of Congo.

24 International Justice Project, Cuzzolino A, 'Cooperating on Non-Cooperation: a brief legal history and analysis of Sudan's non-compliance with the ICC — and the role of the Security Council', 26 June 2015. http://www. internationaljusticeproject.com/cooperating-on-non-cooperation-a-brief-legal-history-and-analysisof-sudans-non-compliance-with-the-icc-and-the-role-of-the-security-council on 20 August 2015. 
ute, and cannot claim to correctly base its powers on custom, when the requirements for forming custom in public international law have not been met as seen in a number of its decisions. ${ }^{25}$

The situation may be different, with regard to entities such as the International Criminal Tribunal for the former Yugoslavia and the International Criminal Tribunal for Rwanda, which get their powers from the United Nations as an extension of the functions of the Security Council; what remains, however, is the fact that the international legal persons who sit in the United Nations, and specifically the United Nations Security Council are states. States can therefore be said to have the front seat in international criminal justice, and are the crucial players in the formation of international criminal courts and the application and enforcement of international criminal law.

\section{i. Divergence of state obligations in the international criminal court, the United Nations ad hoc tribunals and the hybrid courts}

Antecedent to the formation of the ICC, the international criminal tribunals that existed were all ad hoc. This means that they were created to specifically address certain international law violations that had occurred at the (material) time of their formation. ${ }^{26}$ These ad hoc tribunals are set up by the United Nations Security Council, pursuant to the powers accorded in chapter VII of the UN Charter. ${ }^{27}$ Examples of these are the Nuremberg tribunals that were formed after World War II, the International Criminal Tribunal for the former Yugoslavia (herein after referred to as the ICTY) that was formed after mass atrocities were committed in the former Yugoslavia since 1991, and the International Criminal Tribunal for Rwanda (herein after referred to as the ICTR) after the 1994 genocide that occurred in Rwanda. The ICTY and ICTR were established pursuant to the Security Council's powers under chapter VII of the UN Charter. ${ }^{28}$ Special hybrid courts, such as the special tribunals for Sierra Leone and for

25 Custom is created by both the objective element of state practice and the subjective element of opinion juris, as per Article 38 of the statute of the International Court of Justice.

26 International Justice Project, Cuzzolino A, 'Cooperating on Non-Cooperation: a brief legal bistory and analysis of Sudan's non-compliance with the ICC — and the role of the Security Council', 26 June 2015. http:// www.internationaljusticeproject.com/cooperating-on-non-cooperation-a-brief-legal-history-andanalysis-of-sudans-non-compliance-with-the-icc-and-the-role-of-the-security-council, 20 August 2015.

27 Article 41, UN Charter. http://www.un.org/en/sc/repertoire/subsidiary_organs/international_tribunals.shtml on 12 August 2015. See also, Shaw, International Law, 399.

28 Shaw, International Law, 402, 407. 
Lebanon, although not formed by the United Nations charter, are formed in post-conflict situations where the domestic mechanisms for resolving the issue were not adequate. ${ }^{29}$ We then have the ICC, the first permanent court of its kind that was established by treaty between the nations signatory to the Rome Statute.

The purpose of distinguishing these various types of international criminal tribunals is to find out the cooperation structures they adopted, and, in contrast, the ones available to the ICC and the effects thereof. In the preceding part, we identified a particular challenge that the Court undergoes, with regards to cooperation, as it is entirely dependent on the will of the state. This part seeks to outline the differences in terms of cooperation structures that the different types of international tribunals employ, and analyse the solutions that the ICC has adopted. Seeing as prima facie, it is clear that cooperation difficulties have plagued the court immensely.

\section{ii. Courts established by United Nations Security Council}

The United Nations Security Council, pursuant to its powers under chapter VII of the United Nation's Charter, establishes judicial bodies that are formed for the purpose of continuing its work of maintaining peace and security the world over. ${ }^{30}$ Since the Security Council does not possess the power to perform judicial functions or, in this case, to exercise jurisdiction on individual criminal responsibility matters, it delegates some of its powers to the international criminal tribunals that it creates, as was seen in the report by the Secretary General of the United Nations to the Security Council. ${ }^{31}$ The Tadic case in the ICTY reiterated this power of the Security Council. ${ }^{32}$

The mandate of these international tribunals is to be further determined by chapter VII of the UN Charter. ${ }^{33}$ The tribunals may also be given delegated powers by the Security Council. This means that their powers and functions may be from the charter expressly or implied whereby the council delegates its powers to the tribunals to perform judicial functions. ${ }^{34}$ Implied powers are those

\footnotetext{
29 Shaw, International Law, 417.

30 Sarooshi D, Powers of the United Nations Criminal Tribunals, Max Plank Year Book of United Nations Law. See also, the United Nations Charter, Chap VII.

31 Report of the Secretary-General pursuant to Paragraph 2 of the Security Council resolution 808, 3 May 1993 UN Doc S/25704, 7.

32 Prosecutor v Tadic, ICTY, Case No. IT-94-1-T, 1997.

33 This is the express source of power; i.e. that are granted by the United Nations Charter Chapter VII. There also exists implied powers that stem from the fact that they are judicial organs.

34 Reparations case, 47, 56-57. It was said here that the organization must have those powers conferred to
} 
that are deemed to be necessary for the fulfilment of their obligations as courts. This was set out in the advisory opinion by the International Court of Justice in the case of the reparation of injuries suffered by the agents of the United Nations. ${ }^{35}$

The tribunals established by the Security Council enjoy a certain level of independence and autonomy over their actions and decisions, because of the judicial functions conferred on them. The Security Council in practice does not interfere or review the court's decisions, because in this case it would be performing judicial functions, which it has no power to do. The Security Council's mandate is to form these judicial bodies, as seen earlier, and not to perform these functions itself. The independence that is enjoyed by these bodies assists in the adequate and efficient performance of the functions of the court. Although they also depend on their situation countries for cooperation, the obligation to cooperate stems directly from the Security Council's delegated power and is then easier to enforce. When the ICTY was being formed, the Secretary General stated that the court should be enabled to perform its specific functions, independent of the political considerations of the Security Council, and it was not subject to the command of the Council. ${ }^{36}$ This aspect of independence is crucial for the functions of the court. The decisions that the courts give are also binding on all states, by virtue of the fact that the Security Council delegated that power, and, therefore, these could be said to be the decisions of the council itself in this way. The Security Council has the powers to issue resolutions binding upon all states under Article 25 of the UN Charter. ${ }^{37}$ In this way any delegated function can be deemed their own and thus binding upon all states.

There exists in international law the principle, par in parei, non babet imperium, that among equals, none has dominion over the others. ${ }^{38}$ This stems from the principle of sovereignty. There is an exception to this rule as regards the powers of the Security Council, particularly in relation to cooperation. The aspect of the extended powers of the Security Council to the court, flows to the issue of cooperation. The obligation of states to cooperate is outlined in Article 29 of

it that are absolutely necessary for the fulfilment of the functions. The purpose of an organisation can give rise to its implied rights and duties.

Reparation case, 174.

36 UN, Report of the Secretary-General pursuant to Paragraph 2 of the Security Council resolution 808, 1993.

37 Article 25, UN Charter. The member states are to accept in all ways and execute the decisions of the Security Council, and subsidiary organs as long as the scope of powers transferred by the Security Council is strictly observed.

38 Encyclopaedic Dictionary of International Law, 3ed, Oxford University Press, 2009. 
the Charter, and in particular to the ICTY, in paragraph 4 of the Security Council resolution that formed it. ${ }^{39}$ Since binding force arises from Article 29, the provisions of Chapter VII, as well as statutes of the tribunals, then the obligations of each member state to cooperate, is binding upon all. The duty to offer judicial assistance and cooperate with the court is therefore compulsory, and no derogation can be permitted. This therefore ascertains that the cooperation requests made by the court(s) are to be binding. ${ }^{40}$ The ICTY in the Blaskic Subpoena case, however, mentioned that when there was a requirement by the courts that documents be produced, they must be of a specific nature. ${ }^{41}$

The last issue regards the situation in which there would be a conflict of obligations to cooperate with the courts, and another treaty-based obligation. Since the courts are established by the UN, this issue is dealt with by the UN Charter, which provides in Article 103, that, in the event of conflict, the obligations under the UN Charter shall trump those of the other treaty. The statutes of both the ICTY and ICTR, as seen here, contain provisions of mandatory cooperation, because they were created by the Security Council. ${ }^{42}$

\section{iii. Hybrid courts}

Although the dynamics and practice surrounding Special Hybrid Tribunals is relevant to the discussion on international criminal tribunals, for the purposes of this paper we shall limit our discussion to the other types of courts, but shall nonetheless discuss it in small detail. The special courts are not created by the United Nations under the charter but as mentioned in the introduction, they are created as an agreement by the United Nations and specific countries, as was the case in Sierra Leone. The state obligation mechanisms used by these special tribunals are those that involve getting into special treaties with the countries involved. The Sierra Leone court executed treaties with the countries involved; so did the Lebanon tribunal, although it was seen to only enter into a memorandum

39 UNSC S/RES/827 (1992) Establishment of ICTY, para 4.

40 Prosecutor v Tihomir Blaskic, Judgement on the request of the Republic of Croatia for review of the decision of Trial chamber 11, 1997, Para 26.

41 Frowein J.A and Zimmerman A, 'Amicus Curiae in Blaskic Subpoena Case before appeals chamber', Max Plank Institute for Comparative Public Law and International Law.

42 It is important to note however, that earlier courts established by the United Nations such as the Nuremberg Tribunals, and the Tokyo Tribunal, did not give rise to the issue of cooperation, because the trials were conducted when the suspects were already in custody, and therefore the court need not ask for states to cooperate. 
of understanding with Lebanon itself. ${ }^{43}$ These special treaties executed between the courts and the countries involved are an effective way to enforce state obligation, since it is a general rule, under the Vienna Convention on the Law of Treaties that every treaty in force is binding upon the parties to it and must be performed by them in good faith. ${ }^{44}$

\section{iv. The International Criminal Court}

The issue of state obligation, and in particular the obligations of states to cooperate with the court, is one that has in recent years threatened to completely terminate the life of the ICC. With regard to the continent, questions have been raised on the viability of the court and whether the court will be able to effectively exercise its functions, without adequate cooperation by the states. This takes us back to one of the demerits of having states as primary actors in international criminal tribunals, more so, for the ICC. Part III of this paper will extensively deal with the specific issues of the state's obligation, that is, the issue of the obligations of states party to the Rome Statute to execute arrest warrants that are issued by the court. There has been a conflict of obligations, in relation to this issue, with one of the questions asked being whether the Rome Statute is airtight in its provision (as regards this issue).

It is important to outline clearly the differences between the obligations that arise from the Rome Statute and the obligations that arise from the United Nations Charter and Security Council resolutions. To do this, this paper will analyse the various provisions of the Rome Statute in regard to state obligations. As a preliminary point, it is paramount to this discussion that it is reiterated that the ICC was established by the Rome Statute and not the United Nations. The fact that it was not formed by the United Nations is a starting point, to the clear demarcation of state obligations that arise. All parties to a treaty are under an obligation to perform in good faith their duties under that treaty. This is the principle of Pacta Sunt Servanda that is provided for by the Vienna Convention on the law of treaties, in Article 26. This means that the treaty is binding in force, and every state party to it has an obligation to perform its duties in good

43 International Justice Project, Cuzzolino A, 'Cooperating on Non-Cooperation: a brief legal history and analysis of Sudan's non-compliance with the ICC — and the role of the Security Council', 26 June 2015. http:// www.internationaljusticeproject.com/cooperating-on-non-cooperation-a-brief-legal-history-andanalysis-of-sudans-non-compliance-with-the-icc-and-the-role-of-the-security-council on 20 August 2015.

44 Article 26, Vienna Convention on the Law of Treaties, 23 May 1969, 1155 UNTS 331. 
faith, ${ }^{45}$ as well as not to defeat the purposes of the treaty, under Article 18 of the VCLT. ${ }^{46}$

Having noted that the obligations that states have under a treaty are binding in force, the paper will set out to analyse the Rome Statute provisions applicable. Article 86 provides the general obligations of state parties to cooperate fully with the court in the investigation and prosecution of crimes, as well as in any other form as outlined by Article $93 .{ }^{47}$ The court has the powers to request cooperation from any state party, failure to which, the court may make a finding, and refer the matter to the Assembly of State Parties (ASP); or where the matter was brought into the court's attention by the Security Council, it may refer it to the Security Council. ${ }^{48}$ Despite the fact that the refusal of a state to cooperate with the court hinders the court from exercising its powers and functions, contrary to the provisions of the statute, there is no mention of what exactly would constitute an action that the ASP or the Security Council could take. ${ }^{49}$

As regards non-state parties, the court may invite the state to provide assistance to the court, on an ad hoc basis through an agreement with the state. The court also takes the same actions that it takes on state parties, in the event that the state fails to comply with the court; that is, refer the matter to the ASP or the Security Council where applicable..$^{50}$

State obligation to assist the court may take different forms, such as the obligation of a state party to surrender persons to the Court, under Article 89. ${ }^{51}$ This obligation to arrest a person whom an arrest warrant attaches, has been the bone of contention recently, especially in regard to the request for the arrest of Omar al Bashir, which many African countries have failed to honour. ${ }^{52}$ There are, however, various other ways in which states are obligated to assist the court. ${ }^{53}$

\footnotetext{
Article 26, Vienna Convention on the Law of Treaties.

46 Article 18, Vienna Convention on the Law of Treaties. This, however, relates to the point where the treaty has been signed, but not ratified, or where the treaty is yet to come into force. It could, however, still be used as a persuasive argument.

47 Article 86 and 93, Rome Statute of the International Criminal Court.

48 Article 87 (1) (2), Rome Statute of the International Criminal Court.

49 Article 87(7), Rome Statute of the International Criminal Court.

50 Article 87 (5) (b), Rome Statute of the International Criminal Court.

51 Article 89, Rome Statute of the International Criminal Court.

52 Non-cooperation decisions have been issued by the ICC against Malawi, Chad and the DRC. The decision in respect of Kenya is pending.

53 Article 93, Rome Statute of the International Criminal Court, which outlines all the various forms of cooperation. The identification and whereabouts of persons; the taking of evidence, including testimony under oath, and the production of evidence, expert opinions and reports necessary to the Court, facilitating the voluntary appearance of persons as witnesses or experts before the Court, as
} 
An important provision, which will form a large part of the discussion in part III, is Article 98, which is on cooperation with respect to immunity and consent to surrender. Under this provision, the court shall not proceed to request the surrender of an accused or assistance thereof, when the requested state would have to act inconsistently with its obligations under international law with respect to diplomatic immunity of a person of another state, unless the court can gain a waiver of that immunity from that state. ${ }^{54}$ When the third state does not give consent for the surrender of a person, the court should not proceed with the request for surrender, since this would be make the state act inconsistently with its obligations under international law. This has formed the crux of the debate between the AU and the ICC, as regards the arrest of Sudanese President Omar al Bashir. ${ }^{55}$

Here, a conflict in the two provisions of the Rome Statute stated above is seen, whereby the obligation of a state to cooperate with the court is clearly outlined, but then comes a provision which states that the court may not proceed with a request for cooperation where the requested state would have to act inconsistently with its obligations under international law. With regard to the specific issue of arrest warrants, these two provisions pose a difficulty in the analysis of the law.

In conclusion, on analysis of state obligations that accrue from the United Nations tribunals, and those that come from the Rome Statute, it would not be far-fetched to state that the obligations to cooperate with the ad hoc tribunals are weightier because of their constitutive documents as well as the fact that these tribunals have primacy over national proceedings while the ICC has complementary jurisdiction. ${ }^{56}$ Although the Rome Statute, being a treaty, gives the obligations to all state parties to perform their duties in good faith; in the case of conflict between it, and any other treaty, it is not clear what agreement should trump the other. Furthermore, upon a request by the court for a state to cooperate that will make a state act in contravention of its international law obligations, the court shall withdraw such a request, in addition to the fact that the state so requested shall not be bound to perform its obligations to comply. In contrast, the tribunals formed by the Security Council have more binding obligations. This

in Kenya's situation; the execution of searches and seizures and the protection of victims and preservation of evidence.

54 Article 98(1), Rome Statute of the International Criminal Court.

55 African Union, Motion on cooperation with the ICC, Assembly/AU/Dec, 243-267.

56 Article 17, Rome Statute of the International Criminal Court. 
is because, pursuant to the United Nations Charter, the Security Council may make binding resolutions on all state parties. ${ }^{57}$ By virtue of the Security Council's delegation of powers to the tribunals, the tribunal's decisions are therefore considered as the council's own, and therefore just as binding on all states. In addition to this, the UN Charter specifically provides that in the event of a conflict of obligations between that of the Charter and that of another treaty, the provisions of the charter shall supersede.

It is sufficient to say that there is need for the amendment of the Rome statute so that the provisions are clearer and therefore the obligations are construed as mandatory in order to allow for the effective functioning of the Court. The lack of clarity in the statute as regards the issue of state obligations to cooperate with the ICC creates up a slippery slope effect, where instances of states failing to comply occur every now and then, as is evident in the practice of the court. ${ }^{58}$

\section{Cooperation of African countries in the ICC}

The ICC's image in Africa has been characterised by numerous dissatisfactions in the workings of the court. ${ }^{59}$ This has been due to the position that most African countries hold, that the court targets African leaders and is not based on an objective manner of pursuing situations of conflict, but is rather guided by political considerations. ${ }^{60}$ Perhaps if the court instituted proceedings in other situations outside Africa, the image of the court in the continent's eye would improve. Indeed, questions somewhat valid in their own right have been raised as to why situations in Palestine, the United States' conduct in Iraq, and many other such conflict-ridden situations have not been taken up the ICC, or why the Security Council has not taken any actions pertaining to these.

Article 24, UN Charter.

58 Botswana, Chad, Central African Republic, China, Democratic Republic of Congo, Djibouti, Ethiopia, Egypt, Eritrea, France, Iran, Iraq, Kenya, Kuwait, Libya, Malawi, Malaysia, Nigeria, Qatar, Saudi Arabia, South Africa, South Sudan, Turkey, Uganda, Zambia See, Bashir Travel Map http:// bashirwatch.org/. On 21 August 2015.

59 'Bosco D: Time for the African Union to choose a Path' International Criminal Justice Today, 8 December 2014. http://www.international-criminal-justice-today.org/arguendo/Article/time-for-theafrican-union-to-choose-a-path/on 13 August 2015.

60 African Union, Motion on cooperation with the ICC. Assembly/AU/Dec. 243-267 (XIII). The formal position stems from the various decisions by the $\mathrm{AU}$ as regards the matter. 
International tribunals are in many ways the power play table of many powerful countries. Political realities within the realm of the functioning of the courts, in particular the ICC, need to be acknowledged for what they are. ${ }^{61}$ It is not, however, within the scope of this chapter to discuss the reasons and analyse these claims, but this (nonetheless) gives a very good basis of understanding the discontent that the African continent as a whole has towards the ICC. Oversimplifying the views of the continent by just looking at the stand of the AU has been discouraged, however. ${ }^{62}$ States such as Botswana, as well as many other African states party to the Rome Statute as earlier seen, have publicly raised concerns over the declarations of the AU, citing their continued support for the ICC. ${ }^{63}$

The AU has, however, threatened to withdraw from the Rome Statute, although this claim has not materialized, and will probably not in the coming years. ${ }^{64}$ The reality still remains however, that there is adequate precedent showing the continued prevalence in prioritizing African cases over others because of the politics that plague the world we live in. The court has clearly avoided taking up cases that will implicate powerful nations. Even so, African states, and in large numbers, have signed on to the Rome Statute, which has exposed them to many legal implications and cannot use deceptive and subjective non-legal arguments for their dissatisfaction with the court.

In addition to the claims by the AU that the ICC is a political tool of the powerful and is unfairly targeting African states, there come about different positions as regards many issues such as those of state sovereignty, immunities applicable to heads of states and the general duty to cooperate with the Rome Statute. A prevalent position of the AU is that sitting heads of state still enjoy immunity even for international crimes, and this will form a major part of our

${ }_{61}$ 'Bensouda F: ISS Seminar: Setting the record straight: the ICC's new Prosecutor responds to African concerns' ISS, 10 October 2012 http://www.issafrica.org/eventitem.php?EID=864 on 16 August 2015.

62 'Bosco D: Time for the African Union to choose a Path' International Criminal Justice Today.

63 'Kersten M: Backing the ICC: Why Botswana stands alone amongst AU States' http://justiceinconflict.org/2013/06/13/backing-the-icc-why-botswana-stands-alone-amongst-au-states/ on 25 November 2015.

Examples of other states in support of the ICC, are Madagascar, Senegal, Malawi and Nigeria. See Human Rights Watch, 'Memorandum to African States Parties of the International Criminal Court for the Assembly of States Parties 14th Session', 17 December 2015. https://www.hrw.org/news/2015/11/17/ memorandum-african-states-parties-international-criminal-court-assembly-states on 28 November 2015.

64 AU Assembly, Decision on International Jurisdiction, Justice and the International Criminal Court (ICC) Doc. Assembly/AU/13(XXI) adopted at the 21 $1^{\text {st }}$ ordinary session held in Addis Ababa, Ethiopia, 2013. 
discussion. The ICC has a number of times, in a somewhat clumsy way, rejected this argument citing customary law among other authorities. A detailed discussion of this issue is to be carried out in this chapter. ${ }^{65}$

The conflict between African states and the ICC arose when the ICC prosecutor issued an arrest warrant for Omar Al Bashir. In 2008, the AU through its Peace and Security Council requested that the proceedings against $\mathrm{Al}$ Bashir be suspended. In 2009, the AU made a decision which was majorly orchestrated by Muammar Gadaffi, which called on the member states of the AU, notably all African countries, to refuse to cooperate with the court, by virtue of Article 98 of the statute. ${ }^{66}$

Pursuant to the persistence of states party to the Rome Statute and to the AU, when the Union met in Kampala in 2010, it dropped the hostile wording of its declaration, while still maintaining its position. However, it provided that those states party to the AU and the Rome Statute should balance their obligations to the AU with their obligations to the ICC. ${ }^{67}$ The act of 'balancing' obligations in this sense can be taken to mean that while the African nations uphold their duties towards countries such as Sudan, as stipulated in Article 98 of the statute, they should at the very least make sure that persons against whom arrest warrants have been issued such as Bashir should not step into their countries.

Kenya, Chad and Djibouti had at this time hosted President Bashir, in a couple of situations, in complete contravention of their duties and obligations under the Rome Statute. The AU then reaffirmed its position, by stating that the acts of Kenya and the rest were pursuant to Article 23 of the constitutive Act of the African Union. ${ }^{68}$ There have been other arguments that some countries, particularly Chad, which was in conflict with Sudan but had just recently got out of it, were acting for reasons of maintaining peace and stability in their regions. ${ }^{69}$ The ICC on several occasions issued various decisions regarding the non-cooperation in various African countries such as Chad, Malawi and the Democratic

65 In international law, there exists a general rule that there is no immunity for crimes of an international nature, such as war crimes, genocide and crimes against humanity. The Rome statute contains this provision in Article 27, but it is contradicted in Article 98.

${ }_{66}$ The AU has a membership of all 54 African countries. See, http://au.int/en/countryprofiles on 28 November 2015.

67 Plessis M and Gerves C, 'Balancing Competing Obligations: The Rome Statute and AU decisions' Institute for Security Studies, (2011).

68 Article 23, Constitutive Act of the African Union.

69 Plessis M and Gerves C, 'Balancing Competing Obligations: The Rome Statute and AU decisions' Institute for Security Studies, 2011. 
Republic of Congo (DRC) for failure to comply with the arrest warrant execution obligation of Omar al Bashir. ${ }^{70}$

The Kenyan situation that was brought about proprio motu by the then ICC prosecutor Louis Moreno Ocampo also brought about a number of issues with regard to the relationship between the court and the AU. ${ }^{71}$ Issues such as the prosecution of a sitting head of state have arisen, and some changes to the ICC rules of Procedure and Evidence to relieve defendants, for example, a head of state from being present during the subsistence of the trial, have all arisen from the Kenyan situation. ${ }^{72}$

\section{i. Immunities in the International Criminal Court: The Article 27 and 98 debate}

The two contentious provisions that have formed the basis of the debate of the existence of conflict between the African Union and the ICC are Article 27 of the Rome Statute as well as Article 98. It is important that before reconciling the two provisions, and forming an argument as concerns immunity, they be separately analysed.

\section{a) Immunities under Article 27}

It is a general principle of domestic law that heads of states, heads of government and ministers of foreign affairs have the privilege of enjoying certain immunities from prosecution. ${ }^{73}$ However, the practice of international criminal law precludes any such immunities in respect of war crimes, crimes against humanity and genocide. These are among the crimes that the ICC has jurisdiction over. In Article 27 of the Rome statute states that the statute shall apply without any distinction and that official capacity, in particular, that of a head of state, will not exempt any person from criminal responsibility, nor shall it constitute a ground for the reduction of a sentence. ${ }^{74}$ This Article clearly precludes immuni-

\footnotetext{
70 'Bosco D: Time for the African Union to choose a Path' International Criminal Justice Today, 8 December 2014 http://www.international-criminal-justice-today.org/arguendo/Article/time-for-theafrican-union-to-choose-a-path/ on 13 August 2015.

71 The Kenyan situation was the first proprio motu situation in the ICC. Also first prosecution of a sitting head of state.

72 Assembly of State Parties to the Rome Statute, Resolution adopted at the $12^{\text {th }}$ plenary meeting, on $27^{\text {th }}$ November 2013, ICC-ASP/12/Res 7, 53. https://www.icc-cpi.int/iccdocs/asp_docs/Resolutions/ ASP12/ICC-ASP-12-Res7-ENG.pdf on 28 November 2015.

73 Arrest Warrants Case, (DRC v Belgium) Advisory Opinion, ICJ Reports 2002, 36.

74 Article 27, Rome Statute of the International Criminal Court.
} 
ties of heads of state or government from the jurisdiction of the court. It should be noted then that this Article concerns immunities before the court, and should be distinguished from Article 98 which is discussed below.

Contention has arisen, however, as to the applicability of Article 27. It is argued that Article 27 does not apply to non-state parties to the ICC. This was pointed out by the $\mathrm{AU}$ in its non-cooperation decision. ${ }^{75} \mathrm{~A}$ contrary argument has been put forward, that even though the Article is not applicable to non-state parties, that in respect of countries such as Sudan, there are still no applicable immunities. ${ }^{76}$ This is first and foremost because of the fact that the situation in Sudan was referred to the court by the Security Council under resolution 1593 . Because the Security Council chose to refer the situation to the court, it can be logically presumed that it expected an initiation of investigation and prosecution thereof. The fact that this can be presumed, also logically implies that the Security Council removed all immunities applicable to Sudan by virtue of this, in order to enable the court to function without any restraints in handling the Darfur situation. ${ }^{77}$ The second reason why the immunities that might attach to Al Bashir no longer attached to him is by virtue of the fact that the Security Council resolution expressly places Sudan under an obligation to cooperate fully with the court. ${ }^{78}$ By virtue of this, it reasonably expects that Sudan should waive the immunity of Al Bashir in accordance with the provisions of the Security Council resolution.

\section{b) Immunities under Article 98}

The immunity under Article 98 is immunity in respect of states vis-à-vis states. There is a general international law duty that states owe each other, that is to provide immunity to heads of states in their territories. ${ }^{79}$ Article 98(1) of the Rome Statute is with respect to waiver of immunity and consent to surrender. Under the Article, the court may not proceed with a request for surrender or assistance, which would require the requested state to act inconsistently with its

\footnotetext{
75 African Union, Decision of the Meeting of African States Parties to the Rome Statute of the International Criminal Court (ICC) UN Doc Assembly/AU/13(XIII), 3 July 2009, para 10.

76 'Bosco D: Time for the African Union to choose a Path' International Criminal Justice Today, 8 December 2014 http://www.international-criminal-justice-today.org/arguendo/Article/time-for-theafrican-union-to-choose-a-path/. On 13 August 2015.

77 'Gevers C: The ICC Pre-Trial Chamber's Non-Cooperation Decision on Malawi' War and Law, 16 Feb 2012, http://warandlaw.blogspot.co.ke/2012/02/icc-pre-trial-chambers-non-cooperation.html on 20 August 2015.

78 Pre-trial Chamber of the International Criminal Court, Decision requesting observations about Omar AlBashir's recent visit to Malawi in October 2011, ICC-02/0501/09.

79 Article 29-36, Vienna Convention on Diplomatic Relations, 18 April 1961, 500 UNTS 95.
} 
obligations under international law, with respect to the state or diplomatic immunity of a person or property of a third state..$^{80}$

The question then arises, as to whether if states comply with the request of the ICC in respect of Al Bashir's arrest, they would be acting inconsistently with any obligation owed to Sudan. Article 27, in as much as it addresses immunities before the court, does not also preclude immunities under customary international law that $\mathrm{Al}$ Bashir enjoys vis-à-vis other states. The formulation of Article 98 foresees this contingency and therefore provides that the court shall not continue with such a request if the state has any such obligation. This has been the basis of the AU's arguments in favour of its members not complying with the request by the ICC to arrest Omar $\mathrm{Al}$ Bashir. A simple argument in favour of the ICC would be that the resolution by the Security Council, stripped Al Bashir of immunities before the Court, and therefore arguably stripped any obligations that he had vis-à-vis other states. This would be a good argument when using the doctrine of effective construction, but otherwise would be incomplete. ${ }^{81}$

When looked at keenly, the wording of the Security Council's resolution is wanting. It only gives an express obligation to Sudan to cooperate but otherwise only merely 'urges' all other states concerned and their regional counterparts to cooperate fully with the court. ${ }^{82}$ The lack of mandatory wording in the resolution, in respect of cooperation, leads to a lack of clarity in the issue. It therefore does not override Article 98, which implies that there exists diplomatic immunity, but rather acts as a persuasive provision.

Nevertheless, there are arguments that tend to water down the effect of Article 98 which the pre-trial chamber issued, although a number of difficulties are deduced with these. The first argument by the court is that, under customary international law, immunities are non-existent in international tribunals. ${ }^{83}$ The pre-trial chamber of the ICC, in dealing with the issue of Malawi's non-cooperation, stated that dating back to the post-World War II period, immunities for government leaders and officials was always denied, with no deviation given to this stand. Most of the pre-trial chamber's examples that showed the non-exist-

80 Article 98(1), Rome Statute of the International Criminal Court.

81 Doctrine of effective construction precludes the interpretation of an Article of the law that renders other parts of it inapplicable. It is the doctrine, that 'the thing may rather have effect than be destroyed. See Langan P, Maxwell on Statutory Interpretation, 12 ed, Sweet \& Maxwell, London, 1969, 45.

82 UNSC S/RES 1593 (2005) Resolution with regards to the report of the inquiry into human rights violations in Darfur, 1.

83 Pre-trial Chamber of the International Criminal Court, Decision requesting observations about Omar AlBashir's recent visit to Malawi in October 2011, ICC-02/0501/09. 
ence of immunities were faulty on their own. The chamber cited among others, the Statute of the International Military Tribunal, the Tokyo Tribunal, the ICTR AND ICTY statutes, the Arrest Warrants case by the ICJ and the 1919 commission on the responsibility of the Authors of War and on Enforcement of Penalties. ${ }^{84}$ Take for example the 1919 Commission on the Responsibility of Authors of War, where the German Emperor Wilhelm II, who was to be on trial, was not an emperor at the time that the commission wrote the report. This renders the use of this as compelling evidence of the preclusion of immunities in customary international law insufficient to a certain extent. The only viable source of this custom named by the pre-trial chamber was the decision in the ICJ of the Arrest Warrants case. It should also be noted that since the issue in this case was discussed in passing, one can argue that it does not sufficiently address the issue of immunities vis-à-vis other states as contemplated by Article $98 .{ }^{85}$ However, the belief on the arrest warrants case was well placed.

The second argument given by the court regarding the inapplicability of Article 98 is still related to custom, but will be analysed from a different tangent. The ICC Pre-trial chamber seems to formulate the argument that since PostWorld War II, there has been formation of custom. The argument for the formation of custom here is somehow faulty, as it takes into account only the objective element of practice, but fails to take into account the subjective element, as expressed by Shaw, that is the element of Opinio Juris Necessitas. ${ }^{86}$ This is the element of a state behaving the way it behaves, because it has a legal obligation to do so. The two, state practice and opinio juris, form custom. ${ }^{87}$ The court does not take this into account in deciding that immunity does not exist because of customary international law. ${ }^{88}$ Some writers have termed this the 'cheerleader effect', which is the court's way of trying to prove something, when they don't have a case. ${ }^{89}$

The pre-trial chamber, according to this analysis, should not have taken into account the provision of Article 27. Article 27 clearly precludes the existence of

84 'Jacobs D: Does South Africa have an obligation to arrest and surrender Bashir to the ICC? No,' Spreading the jam, 14 June 2015, http:/ / dovjacobs.com/2015/06/14/does-south-africa-have-an-obligation-to-arrest-and-surrender-bashir-to-the-icc-no/ on 20 August 2015.

85 Arrest Warrants Case, (DRC v Belgium), 36.

86 Shaw, International law, 72.

87 Article 38, Statute of the International Court of Justice.

88 See, Shaw, International law, on the criteria for formation of custom.

89 Jacobs D, 'A Sad Hommage to Antonio Cassese: The ICC's confused pronouncements on State Compliance and Head of State Immunity' Spreading the jam, 15 December (2011), http://dovjacobs. com/2011/12/15/a-sad-hommage-to-antonio-cassese-the-iccs-confused-pronouncements-onstate-compliance-and-head-of-state-immunity/ on 21 August 2015. 
immunity in respect to those crimes mentioned in the Rome Statute; therefore, in that case, $\mathrm{Al}$ Bashir did not have immunity as regards the jurisdiction of the court over the matter. The real issue, was the issue of the immunities $\mathrm{Al}$ Bashir had in relation to other states, and whether those existed. It is to be noted that the chamber put down a superfluous argument that because the states ratified Article 27 the provisions of Article 98 did not apply. The chamber sets this out, as if to say that the states did not also ratify Article 98. This kind of interpretation renders Article 98 void, which would be misleading. ${ }^{90}$

In conclusion, it is important to note the solutions that could be taken to address the issue of cooperation. At the very least in relation to the situations referred to the ICC by the Security Council, in order to make the obligations under the Rome Statute binding, the Security Council needs to adopt a more clear mandatory wording of its resolutions, so that no derogation from this is permitted. The fact that, for example, in the Darfur situation, the council merely 'urged' states to cooperate with the court shows the inefficiencies brought about by the ambiguity in its resolutions. If in these instances the Security Council is to assist the court, it should adopt strict and, if possible, punitive measures regarding the situations it refers to.

\section{Conflict of interests between the ICC and the African union}

Stemming from all the legal complexities cited in the above part, it is important to discuss the issue of the conflict of obligations that have occurred with regard to the ICC. The AU has cited Article 98 as the basis of its stance. The ICC, on the other hand, has on many occasions tried to water down the effect of Article 98 and has argued on the basis of Article 27 and custom. On the face of it, it is not difficult to see the complexities this issue brings, especially for the states that are party to the Rome Statute, while still party to the African Union.

It is to be noted that some African countries have continually changed their position as regards cooperation with the court for various reasons, political or not. We see, for example, a change in Chad's position, from that of not cooper-

90 'Tladji D: The ICC Decisions on Chad and Malawi on Cooperation, Immunities and Article 98', Oxford Journal of International Criminal Jutsice, (2013), 119-221. See also, Jacobs D, 'Does South Africa have an obligation to arrest and surrender Bashir to the ICC? No' Spreading the Jam, 14 June (2015). http://dovjacobs.com/2015/06/14/does-south-africa-have-an-obligation-to-arrest-and-surrenderbashir-to-the-icc-no/ on 21 August 2015. 
ating with the ICC, to the one it holds now, that it shall cooperate in every way possible. It is noted that initially, in relation to the situation in Darfur, Chad had refused to cooperate with the court, due to the peace and stability they achieved after a long conflict. It was then in Chad's and Sudan's best interests, it reiterated, for it not to cooperate with the court. After a change in regime, when a new head of state came in, Chad then publicly backed the ICC, and vowed to arrest $\mathrm{Al}$ Bashir if he came into their territory. This was seen as a play of politics, whereby the reason for Chad's position was so that the new government would gain favour with the international community as a whole. ${ }^{91}$ Malawi is seen to have changed from a period of willingness to cooperate, to one where it cites its obligations to the $\mathrm{AU}$ as its reason for non-cooperation. There are states, for instance Kenya and South Africa, who in a number of situations have been seen to be in contravention with their obligations under the statute, while showing a clear demarcation between the stand of their judiciaries and the executive arms of government. ${ }^{92}$

The divergence in opinions between the AU and the court exists in a number of issues, as seen above, such as sovereignty of the state, the obligations that arise from the statute, the issues of the need of a head of state to be present in proceedings of the trial, and the immunity of heads of state. The AU has issued a number of non-cooperation declarations with the ICC, in a number of situations, urging its member states not to comply with the requests of assistance by the court. The AU has also stated that it will move to the ICJ, for the court to determine the issue. To date it hasn't done so. Just recently, the AU issued a statement, threatening to withdraw from the Court, ${ }^{93}$ all this while the ICC issues non-cooperation decisions against some African countries. In late August 2015, the appeals chamber reversed the trial chamber's decision in refusing to grant a non-cooperation finding in respect of Kenya.

It is clear that there is a conflict of interest in obligations. Where, then, does the balance lie? Which obligations trump which? The ICC had made a finding,

91 Huffington Post, Mariana Pareja, Chad must cooperate with the International Criminal Court, http:/ /www. huffingtonpost.com/mariana-rodriguez-pareja/icc-indictee-in-chad-why-_b_2696582.html on 25 November 2015.

92 ICJ Kenya, African civil society urges African States Parties to the Rome Statute to reaffirm their commitment, 2009, 30. https://www.hrw.org/news/2009/07/30/african-civil-society-urges-african-states-parties Rome-statute-reaffirm-there on 25 November 2015.

93 Letter to ICC States Parties Ministers of Justice and Ministers of Foreign Affairs on the establishment of an International Criminal Court liaison office in Addis Ababa, Ethiopia, 2009. http:/ /www. coalitionfortheicc.org/documents/Briefing_AU_ICCReview.pdf; 
where it stated that it recognized the assertions of the AU. However, it sought to then declare that the Union's declarations were not viable because they were inconsistent with the statute, and only relied on Article 98 of the Rome Statute. It should be noted that this is essentially false, because the legal validity of the AU's declarations is not dependent on its following the Rome Statute, as it is an organization of its own, and not party to the Rome Statute. ${ }^{94}$

This paper takes the position of the $\mathrm{AU}$ in its first non-cooperation decision as regards this matter and, as stated previously in this paper, when there exists a conflict of obligation between that of the states, that are parties to the $\mathrm{AU}$, and also parties to the Rome Statute, they shall have due regard to their obligations and balance them accordingly, where applicable. ${ }^{95}$ The balancing effect of this is to say that while there still exists a conflict of obligation in this matter, African states should not ignore their obligations under the Rome Statute but should balance the two. This is to be taken to mean that, at the very least, these states should take measures to ensure that persons accused of such heinous crimes under the Rome Statute do not enter their territory.

The concerns that the AU, being a body that represents Africa as whole, have, need to be addressed too. Constant ignoring of the concerns of the body by the Security Council leads to a deeper rift in the relationship Africa has with the ICC and may have further implications as regards the continent, as well as the functioning of the court, in the future.

The Rome Statute provides that 7 years after coming into force, the provisions may be amended. Any member of the ASP may propose amendments to the Rome Statute. The provisions as regards immunity need to be reviewed and amended in order to provide clarity in the application of these provisions, to avoid future rifts.

States should also refrain from direct attacks against the court. It should be noted that none of the states were coerced into ratifying the Rome Statute. That being said, they should refrain from using politics as an excuse or cover-up for their disagreements with the court, when the working of the court does not favour them. Threatening to withdraw from the statute of the court could have extreme implications in the future and these should be considered carefully.

\footnotetext{
94 'Jacobs D: Does South Africa have an obligation to arrest and surrender Bashir to the ICC? No' Spreading the Jam, 14 June 2015 http://dovjacobs.com/2015/06/14/does-south-africa-have-an-obligation-to-arrest-and-surrender-bashir-to-the-icc-no/ on 20 August 2015.

95 AU Assembly, Decision on the Meeting of African States Parties to the Rome Statute of the International Criminal Court, Assembly/AU/Dec.245 (XIII).
} 


\section{Conclusion}

After consideration of all the factors discussed in the paper, one thing that remains is that the African continent needs a system of justice to deal with international crime. The importance of a mechanism that ensures there is no impunity after crimes against humanity are committed is essential for the survival of the continent as well as to ensure that justice is served. This paper however concedes that much needs to be done in pursuance of this goal, for international criminal justice to prevail in society.

Needless to say, the ICC is here to stay. It is not 'dead', as some may term it. Its importance to the continent cannot be trivialised. It is important that Africa works for an ICC that will work, rather than an ICC Africa wants. It is in order that, as a continent, we work well to improve our relationship with the court, for our own good. 